Asian J. Med. Biol. Res. 2016, 2 (1), 107-112; doi: 10.3329/ajmbr.v2i1.27575

\author{
Asian Journal of \\ Medical and Biological Research \\ ISSN 2411-4472 (Print) 2412-5571 (Online) \\ www.ebupress.com/journal/ajmbr
}

\title{
Article \\ Prevalence of poultry diseases in Gazipur district of Bangladesh
}

Md. Kamrul Hassan ${ }^{1}$, Md. Humayun Kabir2 ${ }^{*}$, Md. Abdullah-Al-Hasan², Shobnom Sultana ${ }^{4}$, Md. Shohidul Islam Khokon $^{5}$ and S. M. Lutful Kabir ${ }^{6}$

${ }^{1}$ Veterinary Surgeon, Sreenagar, Munshiganj, Bangladesh

${ }^{2}$ Bangladesh Livestock Research Institute, Savar, Dhaka, Bangladesh

${ }^{3}$ Paragaon Poultry Hatchery Ltd., Bangladesh

${ }^{4}$ Veterinary Surgeon, Central Artificial Insemination and Fodder Production Unit, Savar, Dhaka, Bangladesh

${ }^{5}$ Veterinary Surgeon, Shahjadpur, Sirajganj, Bangladesh

${ }^{6}$ Department of Microbiology and Hygiene, Bangladesh Agricultural University, Mymensingh, Bangladesh

${ }^{*}$ Corresponding author: Md. Humayun Kabir, Bangladesh Livestock Research Institute, Savar, Dhaka, Bangladesh. E-mail: hkabirvet@yahoo.com

Received: 10 March 2016/Accepted: 24 March 2016/Published: 31 March 2016

\begin{abstract}
This study was designed with a view to investigate the prevalence of poultry diseases in Gazipur district of Bangladesh. A total of 679 poultry birds (313 layers, 338 broilers and 28 cockrels) either dead or live were brought for diagnosis of diseases at Gazipur Sadar Upazilla Veterinary Hospital. The diseases were diagnosed on the basis of history, clinical signs and post-mortem findings. The diseases encountered in layers were bacterial diseases $52.29 \%$ (salmonellosis $38.56 \%$, colibacillosis $6.7 \%$, fowl cholera $4.79 \%$ and necrotic enteritis $1.60 \%$ ), viral diseases $23.95 \%$ (avian influenza $2.56 \%$, Newcastle disease $16.61 \%$, infectious bronchitis $3.19 \%$ and avian leucosis 0.64\%), mycoplasmal disease (mycoplasmosis 14.70\%) and protozoal disease (coccidiosis 5.75\%). Salmonellosis was most prevalent disease in age group of $>20$ weeks, while Newcastle disease most common in 8 to 20 weeks of age group. In case of broiler, bacterial diseases $28.99 \%$ (salmonellosis $21.30 \%$ and colibacillosis $7.69 \%$ ), viral diseases $53.24 \%$ (infectious bursal disease $28.99 \%$, Newcastle disease $8.87 \%$ and infectious bronchitis $15.38 \%$ ), mycoplasmal disease (mycoplasmosis $7.1 \%$ ) and protozoal disease (coccidiosis 6.5\%). In cockrels, the most prevalent disease was colibacillosis $35.71 \%$ followed by salmonellosis $28.57 \%$, Newcastle disease $14.28 \%$ and mycoplasmosis $14.28 \%$. So among the diseases, salmonellosis is most prevalent disease followed by infectious bursal disease and mycoplasmosis in different kinds of poultry of Gazipur district of Bangladesh.
\end{abstract}

Keywords: prevalence; poultry diseases; broiler; layer; cockrels; necropsy

\section{Introduction}

Bangladesh is agriculture-based tropical country where over $80 \%$ of the country's 150 million people live in rural areas and are highly depended on agriculture. There are approximately 160 million chickens and 36 million ducks in the total poultry population of Bangladesh (Ahmmad, 2005) and indigenous chickens constitute nearly $70 \%$ of the chicken population (DLS, 2003). In Bangladesh around 8\% of total animal protein for human consumption comes from livestock (BBS, 2000). Meet and eggs are two major source of animal protein, at present chicken contributes $51 \%$ of total meet production of the country though the share of broiler is not separated. Per capita annual consumption of meet in the country is $5.9 \mathrm{~kg}$ which is only $7.38 \mathrm{~kg}$ of universal standard (MoFL, 2006). The consumption of eggs annually per head in the country is 32 against the maximum requirement of 104 eggs (DAS et al., 2008). For the improvement of national health status and the socio economic condition of the people of our country, establishment of broiler and layer poultry farms should be increased. One of the major constrains of the poultry farming is the outbreaks of several devastating diseases causing economic loss and discouraging poultry rearing. The incidence of diseases varies depending on the Geo- 
climatic condition, season, bread and age of the bird. Again, the incidence of particular disease in an area sometimes may be negligible and at other time if may cause havoc. In prevention and controlled strategies of a disease, the epidemiological knowledge of the disease and knowledge about the pathogenesis and pathology of particular disease is prerequisite in the proper diagnosis of the malady is very necessary. Among the various diagnosis procedures necropsy remains in key point. Considering the above mentioned facts the diagnostic investigation on the poultry diseases in Gazipur Sadar Veterinary Hospital, Gazipur was undertaken in order to achieve the following objectives:

a) To observe the prevalence of poultry diseases at Gazipur Sadar Upazilla in Bangladesh.

b) To study the post-mortem lesions of poultry.

\section{Materials and Methods}

\subsection{Selection of study area}

The study was performed at Gazipur Sadar Upazilla Veterinary Hospital, Gazipur, Bangladesh.

\subsection{Duration of study}

The study was conducted from October 2012 to December 2012 over a period of 2 months.

\subsection{Methods of sample collection}

During the study period, lived and killed diseases birds were received at Upazilla Veterinary Hospital of Gazipur Sadar. The diseases were diagnosed on the basis of history, clinical signs and post-mortem lesions. Only in case of avian influenza suspected birds, isolated and collected tracheal and cloacal swab and then rapid antigenic detection test were performed at district livestock hospital laboratory.

\subsection{Laboratory examination for avian influenza by rapid flu detection test}

At first 7/8 drops of Buffer solution is taken in a test tube

$$
\downarrow
$$

Collection of tracheal swab by cotton bud

$$
\downarrow
$$

Cotton swab is put into test tube and mixed properly

$\downarrow$

Then test strip into the test tube and observed 3-4 minute

$\downarrow$

If the upper and lower yellow indicator turned to red color, the test was positive and upper indicator was red and indicator was unchanged, it indicated the test was negative.

\section{Results and Discussion}

The present pathological investigation detected a large number of diseases responsible for the morbidity and mortality of chicks in Gazipur Sadar area. Birds were examined for diagnosis of diseases on the basis of history, clinical sign and post-mortem finding. For confirmatory diagnosis, some microscopic examination and bacteriological test were performed. The proportional diagnosis of different diseases of layer, broiler and cockerels are presented in Table 1. Frequency of different diseases (age wise) in layers, broilers and cockerels are summarized in Table 2. For the convenience of description, the recorded diseases were classified and categorized as viral diseases, bacterial diseases, mycoplasmal diseases, protozoal diseases. 
Table 1. Frequency of different diseases in broilers, layers and cockerels.

\begin{tabular}{|c|c|c|c|c|c|c|}
\hline Type of Diseases & Name of disease & Broiler & Layer & Cockerel & Total No. & $\begin{array}{l}\text { Overall } \\
\text { percentage (\%) }\end{array}$ \\
\hline \multirow{5}{*}{ Viral diseases } & Avian influenza & - & $8(2.56 \%)$ & - & 8 & $1.01 \%$ \\
\hline & $\begin{array}{l}\text { Newcastle disease } \\
\text { (ND) }\end{array}$ & $30(8.87 \%)$ & $\begin{array}{l}52 \\
(16.61 \%)\end{array}$ & $4(14.28 \%)$ & 86 & $12.66 \%$ \\
\hline & $\begin{array}{l}\text { Infectious bursal } \\
\text { disease (IBD) }\end{array}$ & $98(28.99 \%)$ & $3(0.95 \%)$ & - & 101 & $14.87 \%$ \\
\hline & $\begin{array}{l}\text { Infectious } \\
\text { bronchitis (IB) }\end{array}$ & $52(15.38 \%)$ & $10(3.19 \%)$ & - & 62 & $9.13 \%$ \\
\hline & Avian leucosis & - & $2(0.64 \%)$ & - & 2 & $.29 \%$ \\
\hline \multirow{5}{*}{$\begin{array}{l}\text { Bacterial } \\
\text { disease }\end{array}$} & Salmonellosis & $72(21.30 \%)$ & $\begin{array}{l}121 \\
(38.56 \%)\end{array}$ & $8(28.57 \%)$ & 191 & $28.56 \%$ \\
\hline & Fowl cholera & - & $15(4.79 \%)$ & - & 15 & $2.2 \%$ \\
\hline & Collibacillosis & $26(7.69 \%)$ & $21(6.7 \%)$ & $10(35.71 \%)$ & 57 & $8.3 \%$ \\
\hline & Necrotic enteritis & - & $5(1.60 \%)$ & - & 5 & $.74 \%$ \\
\hline & Infectious coryza & - & $2(0.64 \%)$ & - & 2 & $.29 \%$ \\
\hline $\begin{array}{l}\text { Protozoal } \\
\text { disease }\end{array}$ & Coccidiosis & $\begin{array}{l}22 \\
(6.5 \%)\end{array}$ & $18(5.75 \%)$ & $\begin{array}{l}2 \\
(7.11 \%)\end{array}$ & 42 & $6.18 \%$ \\
\hline $\begin{array}{l}\text { Mycoplasmal } \\
\text { disease }\end{array}$ & $\begin{array}{l}\text { Mycoplasmosis/ } \\
\text { CRD }\end{array}$ & $\begin{array}{l}24 \\
(7.1 \%)\end{array}$ & $\begin{array}{l}46 \\
(14.70 \%)\end{array}$ & $4(14.28 \%)$ & 74 & $10.89 \%$ \\
\hline \multirow{3}{*}{ Other diseases } & $\begin{array}{l}\text { Helminth parasitic } \\
\text { infection }\end{array}$ & - & $\begin{array}{l}14 \\
(4.14 \%)\end{array}$ & - & 14 & $2.06 \%$ \\
\hline & Egg peritonitis & - & $4(1.27 \%)$ & - & 4 & $.58 \%$ \\
\hline & $\begin{array}{l}\text { Nutritional } \\
\text { deficiency }\end{array}$ & - & $6(1.19 \%)$ & - & 6 & $.88 \%$ \\
\hline Total & & 338 & 313 & 28 & 679 & \\
\hline
\end{tabular}

Table 2. Frequency of different diseases (age wise) in layers, broilers and cockerels.

\begin{tabular}{|c|c|c|c|c|}
\hline Types of bird & Disease & 0-8 weeks & 8-20 weeks & $>20$ weeks \\
\hline \multirow{13}{*}{ Layer } & Avian influenza & & 8 & \\
\hline & Newcastle disease & 8 & 12 & 32 \\
\hline & Infectious bursal disease & 3 & & \\
\hline & Infectious bronchitis & 1 & 3 & 6 \\
\hline & Avian Leucosis & - & - & 2 \\
\hline & Salmonellosis & 32 & 24 & 65 \\
\hline & Colibacillosis & 14 & 5 & 2 \\
\hline & Fowl cholera & - & 2 & 13 \\
\hline & Mycoplasmosis & 2 & 12 & 32 \\
\hline & Coccidiosis & 8 & 6 & 4 \\
\hline & Necrotic enteritis & - & - & 5 \\
\hline & Egg peritonitis & - & - & 4 \\
\hline & & 0-10 days & 10-20 days & 20-35 days \\
\hline \multirow{7}{*}{ Broiler } & Newcastle disease & 2 & 12 & 16 \\
\hline & Infectious bursal disease & 8 & 22 & 68 \\
\hline & Infectious bronchitis & 0 & 10 & 42 \\
\hline & Salomonellosis & 14 & 38 & 20 \\
\hline & Colibacilosis & 4 & 12 & 26 \\
\hline & Mycoplasmosis & 1 & 20 & 3 \\
\hline & Coccidiosis & 0 & 6 & 16 \\
\hline \multirow{6}{*}{ Cockerels } & & 0-6 weeks & 6- 20 weeks & $>20$ weeks \\
\hline & Newcastle disease & - & 4 & - \\
\hline & Salmonella & 1 & 3 & 4 \\
\hline & Colibacillosis & & 4 & 6 \\
\hline & Mycoplasmosis & 1 & 3 & - \\
\hline & Coccidiosis & 2 & - & - \\
\hline
\end{tabular}




\subsection{Viral diseases}

\subsubsection{Avian influenza}

Out of 679 cases, 8 cases $(1.01 \%)$ of avian influenza were recorded. The farm Kushkhali poultry complex, Konabari, Gazipur has 2500 layer birds. 3 birds were diagnosis by post-mortem and then sample were collected from another 2 birds for confirmatory diagnosis by rapid antigen detection test. After confirmation, all birds were culled.

The clinical sign were as reported by owner and observed during clinical examination of sick birds. The characteristics clinical sign are cyanosis and edema of the head, hemorrhage on the comb and wattle and subcutaneous hemorrhage on the leg shanks.

Gross lesion of avian influenza included foci of hemorrhage in the laryngeal lining. Extensive and severe fibrinous exudates on the air sac, pericardial sac and peritoneum, necrosis in liver and spleen, kidney swollen.

\subsubsection{Infectious bursal disease}

This diagnostic investigation revealed a total of 101 cases $(14.87 \%)$ of IBD of which $98(97 \%)$ cases were in broker at different age and 3 cases 3\% in layer birds under 3 weeks. Within these 101 cases, 8 cases were diagnosed as mixed infection with coccidiosis.

Clinical sign recorded from owners for IBD were depression, inappetance unable to stand vent peeking and diarrhoea. In mixed infection cases, spotted blood are found with diarrhoea.

In most cases of IBD, hemorrhage are found in breast and thigh muscle. Bursa were enlarged then normal with hemorrhage and edematous swelling. In some cases, bursa are atrophied. In many cases, hemorrhage is found in lining of proventiculus and gizzard.

\subsubsection{Newcastle disease}

In this diagnostic investigation, a total of 86 cases (12.66\%) of Newcastle disease were recorded. Among this 30 cases in broiler, 52 cases layer, 4 cases cockrel.

History from owner recorded clinical sign were increased respiration, listlessness, weakness, anorexia, edema around the eyes and head. In some case, greenish diarrheas are found.

In case of ND, relevant lesions recorded at the time of necropsy, included pinpoint hemorrhage in the proventiculus. Hemorrhagic lesions are also found in small intestine and trachea.

\subsubsection{Infectious bronchitis}

In the present investigation, Infectious bronchitis was recorded in 62 cases (9.13\%). At early winter, these types of cases are increased. Out of 62 cases 52 (15.38\%) cases broiler and 10 (3.19) layers.

The clinical sign of IB were recorded sneezing, coughing and rules. Nasal and ocular discharge also found. In case layer, egg production decreased.

Caseous exudates are found in nasal passage and trachea, air saculitis and kidney.

\subsubsection{Avian leucosis}

This investigation recorded a total of 2 cases $(0.29 \%)$ of avian or lymphoid leucosis of which all cases are $>20$ weeks of age.

The histories for clinical sign recorded from owner were inappetence and decrease egg production.

In post-mortem examination the affected liver greatly enlarged, nodular tumors are appeared and moderately firm. The spleens are also enlarged and nodular tumors were found.

Avian influenza is a great threat for poultry industry in Bangladesh. The country first experienced HPAI in early 2007. After the $1^{\text {st }}$ outbreak of AI in March 2007, 4 waves of outbreak occurred in Bangladesh till 2009.AI was recorded to cause $2.56 \%$ death in layer birds. The present study revealed $15 \%$ of IBD was recorded of which the broiler $97 \%$ and layer 3\%. Among the broiler chickens, heavier losses recorded in last stage of age (20-35 days). This findings support the earlier reports of Islam et al. (2003) and Das et al. (2005) who recorded 19.16\%, $24.26 \%, 21.1 \%$ mortality of chickens due to IBD respectively. The disease was characterized by thigh muscle hemorrhage, swollen and edematous bursa, high morbidity and mortality in chicken ass described by Calnek $e t$ al. (1997).

In the present investigation, $13 \%$ of ND causes were found which are agreement with the earlier report of Islam et al. (2005) and Das et al. (2005) who recorded 6.73\%, 7.9\% and $19.5 \%$. The present findings would indicate that the reemergence of ND in commercial flocks is still a threat to the poultry industry in spite of availability use of ND vaccines. Its needs to be investigated if the reemergence of ND is due to vaccination failure or any other factor. 


\subsection{Bacterial disease}

\subsubsection{Salmonellosis}

This pathological investigation revealed a total of 191 cases $(28.56 \%)$ of salmonellosis of which $72(21.30 \%)$ cases are broiler, 121 (38.69\%) layer and 8 (28.57) cases cockrel. Some cases were found as mixed infection with MC complex.

Clinical sign that recorded for salmonellosis were reduced egg production, dullness, anorexia and profuse watery diarrhoea.

In most cases of salmonellosis, liver was enlarged, mottled, with or without white necrotic foci. Spleen was enlarged than normal and whit necrotic foci were found in some cases. In other cases, deformed, degenerated and misshaped ova were found and congested.

\subsubsection{Fowl cholera}

Out of 15 cases $(2 \%)$ of fowl cholera were recorded in this diagnostic investigation of which some were pre laying stage and others were laying stage.

Affected birds showed fever, marked depression, anorexia drop in egg production and greenish color diarrhoea. Observed necropsy findings were petechial hemorrhage on the heart, dark colored liver and pin point white necrotic spot over the liver. Hearts were congested in some cases.

\subsubsection{Collibacillosis}

In this investigation, a total of 57 cases $(8 \%)$ of colibacillosis were recorded. Beside this, colibacillosis was recorded as complex with mycoplasma. Out of 57 cases of colibacillosis. 26 cases (7.69\%), broiler, 21 cases (6.7\%) layer and 10 cases (35.71) cockrels.

Relevant clinical sign of colibacillosis included profuse watery diarrhoea, progressive emaciation, anorexia, paralysis and death which were recorded from the owner's statement.

The lesion as recorded at the time of post-mortem, included white to yellowish fibrinous exudates covering the heart and liver, cloudy air sacs, hemorrhagic spot in heart, liver and spleen.

\subsubsection{Necrotic enteritis}

In this investigation 5 cases $(0.74 \%)$ of necrotic enteritis were observed of which all of them were layer birds. From owner's statement, the birds were severe depression, decrease appetite, reluctance to move, diarrhea and ruffled feathers.

Necropsy finding were distended small intestine and large amounts of hemorrhage observed in lumen in small intestine.

In case of bacterial disease, the present study, $28.12 \%$ of cases of salmonellosis was recorded .This findings support the earlier report of Islam et al. (2003) and Das et al. (2005) who recorded 6.73\%, 24.4\%, and 23.2\%.

The present study, collibacillosis were recorded in $8.39 \%$ which is most nearer to others reports.

\subsection{Mycoplasmal disease}

\subsubsection{Mycoplasmosis}

In the present necropsy investigation, a total of $74(10.89 \%)$ cases of mycoplasmosis were found in broiler and 46 case $(14.7 \%)$ in layer and $4(14.28 \%)$ cases in cockrel.

The clinical sign were as reported by the owner were nasal and ocular discharge, swollen head rales anorexia and poor weight gain.

Gross lesion MC complex included catarrhal exudates in nose and trachea, cloudy fibrinous air sacs, fibrinous pericarditis, severe congestion of lungs with extensive fibrosis were found.

$10.89 \%$ of mycoplasmosis, were recorded in this investigation where earlier report of Saleque et al. (2003) recorded 18.3\% .In many cases, Mycoplasma-colibacillosis complex which are known as chronic respiratory disease ( CRD) were also found.

\subsection{Protozoal diseases}

\subsubsection{Coccidiosis}

In this investigation 42 cases $(6.2 \%)$ coccidiosis observed of which 22 case (6.5\%) broiler and 18 cases (5.75\%) layer.

The farmer's statements were blood spot are found on floor in most cases. The birds are dull and listless with dropping feathers.

The caecum was found to be dilated and contain a mixture of clotted blood. 
Coccidiosis constituted $6.18 \%$ of total cases which is higher than the study of Islam et al. (2003), correlates with the results of Saleque et al. (2003).

\subsection{Other diseases}

\subsubsection{Helminth parasitic infection}

A total of 14 (4.14) cases of helminthes parasitic infections were found in these investigation. The clinical sign were unthriftness, anorexia and emaciation.

The clinical sign recorded farm the owner's statements were depression, anorexia, watery diarrhoea and progressive emaciation.

The intestinal mucosa was markedly inflamed, thickened and hemorrhagic. The lumen of small intestine was picked up with adult worms.

\section{Conclusions}

From this study, 15 types of diseases were diagnosed. On the basis of findings of this investigation, salmonellosis $(28.57 \%)$ is the most prevalent disease followed by infectious bursal disease (14.87\%) and Newcastle disease (12.56\%) in poultry birds. So emphasis should be taken to prevent salmonellosis for development profitable poultry farms. For prevention of infectious bursal disease, Newcastle disease and other diseases proper immunization procedure against these diseases should be undertaken to prevent the mortality of chicks. At present, avian influenza is great threat in our poultry industry. Strict bio-security and continued surveillance of poultry for avian influenza infection is critical to minimize the magnitude of outbreak and limit the risk of human infection.

\section{Conflict of interest}

None to declare.

\section{References}

Bangladesh Economic Review, 2006. Ministry of finance. Government of The People's Republic of Bangladesh, Dhaka, Bangladesh

BBS, 2000. Statistical Pocket Book of Bangladesh. Bangladesh Bureau of Statistics. Ministry of Planning, Govt. of People's Republic of Bangladesh.

Calnek M, 1997. Diseases of Poultry, lowa State University Press, Ames

Chowdhury EH, N Jannat, R Pervin, MAHNA Khan, M Giasuddin and MR Islam, 2009. Investigation of outbreaks of low pathogenic avian influenza virus in poultry farms of Bangladesh. Proceeding of the $6^{\text {th }}$ International Poultry Show and Seminar WPSA-BB; Dhaka, Bangladesh. pp.95-99.

Das PM, DMM Rajib, M Noor and MR Islam, 2005. Antibody response to Newcastle disease vaccines in commercial layer chickens. The Bangladesh Veterinarian, 23: 1-8.

DLS, 2003. Annual Report, Department of Livestock Services. Ministry of Fisheries and Livestock, Govt. Of People's Republic of Bangladesh.

Giasuddin M, MA Samad, MS Khan, P Monoura, MH Al-Faruque, SS Saha and S Sultana, 2009. Outbreak and frequency of circulating strains of avian influenza virus in Bangladesh from 2007-2008. Proceedings of the $6^{\text {th }}$ International Poultry Show and Seminar WPSA-BB, Dhaka, Bangladesh. pp.111-115.

Islam MR, BC Das, K Hossain, NS Lucky and MG Mostafa, 2003. A Study on the occurrence of poultry diseases in Sylhet region of Bangladesh. Int. J. Poult. Sci., 2: 354-356.

Islam MT, MA Islam and MA Samad, 2005. Immunosuppressive effect of infectious brusal disease virus and vaccine on humoral immune response of broiler chickens to Newcastle disease vaccination. Progressive Agriculture, 16: 71-75.

MoFL, 2006. Annual Report, Ministry of Fisheries and Livestock, Govt. of People's Republic of Bangladesh.

Saleque MA, MH Rahman and MI Hossain, 2003. A retrospective analysis of chicken disease diagnosed at the BRAC poultry disease diagnostic center of Gazipur, Bangladesh. J. Vet. Med., 1: 29-31.

Talha AFSM, MM Hossain, EH Chowdhury, ASM Bari, MR Islam and PM Das, 2001. Poultry diseases occurring in Mymensingh district of Bangladesh. The Bangladesh Veterinarian, 18: 20-23. 